\title{
Midwives Productivity in Community Midwifery Services During the Covid-19 Pandemic in Indonesia
}

\author{
Putriatri Krimasusini Senudin ${ }^{1}$, Silfia Norce Halu ${ }^{2}$, Dionesia O. Laput ${ }^{3}$, Yohana Mulyati \\ Dewi ${ }^{4}$ and Matilda H. Betrix ${ }^{5}$ \\ \{atri124@gmail.com ${ }^{1}$, occe.halu@gmail.com²,dinnylaput9@gmail.com ${ }^{3}$, \\ yohanadewi749@gmail.com ${ }^{4}$ ?
}

UNIKA Santu Paulus Ruteng, Indonesia ${ }^{12345}$

\begin{abstract}
Maternal and child health problems have been considered to be national problems in Indonesia. They become top priority issues to be solved because they greatly determine the quality of future generations. Midwives have an important role in overcoming health problems of mothers and children. The duties and responsibilities of a midwife in providing midwifery services in the community are highly dependent on work productivity. Midwifery work productivity is seen from midwifery care in terms of quantity aspects, quality aspects and timeliness. This study aims to analyze the work productivity of midwives in community midwifery services during the Covid-19 Pandemic. The type of research used is an analytical survey research using the crosssectional method. The research sample was 182 people. The results showed that most of the work productivity of midwives in community midwifery services during the Covid19 pandemic was in the good category $(95.6 \%)$, fair work productivity $(3.3 \%)$ and poor work productivity $(1.1 \%)$. The productivity of midwives is carried out by increasing the aspects of knowledge and skills (technical skills). In order to increase the work productivity of midwives, it is necessary to carry out supportive supervision by subdistrict or district supervisors.
\end{abstract}

Keywords: Productivity; Midwife; Community; Covid-19 pandemic

\section{Introduction}

Maternal and child health problems have been the national problems. These problems have to be addressed because they greatly determine the quality of future generations. Maternal mortality rate (MMR) and infant mortality rate (IMR) are one of the indicators used to determine the success of Maternal and Child Health, known as Kesehatan Ibu dan Anak (KIA) efforts. Efforts to improve KIA services need to be carried out jointly and continuously by KIA service implementers at the basic service level and at the referral service level [1].

The quality of KIA services cannot be separated from the role of its human resources. Health human resources are all people whose main activities are aimed at improving health [2]. Midwives are one of the health human's resources who have an important role in KIA services. Community midwifery services carried out by midwives emphasize promotive and preventive efforts without neglecting curative and rehabilitative efforts. The main task of the midwife is to foster community participation through developing Posyandu and group leaders, as well as providing direct services at Posyandu, assisting childbirth and receiving referrals for health problems of family members. The objective of community midwifery services is to 
improve the quality and distribution of health service coverage in order to reduce maternal mortality and birth rates, which is supported by the increase of public awareness to behave in a healthy life [3]

The achievement of community midwifery service objectives can be influenced by the work productivity of midwives. Work productivity is the ability of an employee to manage and utilize the available resources to obtain optimal output or results in the context of carrying out the tasks that have been assigned to him and the achievement of predetermined work results. Work productivity has two dimensions, namely work effectiveness and efficiency. The work productivity indicators can be viewed from the aspects of quantity, quality and timeliness in completing work [4].

The work quantity of midwives is related to the amount of work that must be completed in accordance with their responsibilities and authorities. The number of jobs of midwives working at the Puskesmas will be different from the number of midwives who work as administrators of Polindes, Poskesdes or PKD. It is precisely because they are not only responsible for maternal and child health services, but also health services as a whole ranging from simple medication, surveillance of infectious diseases, nutrition services and service. Too much work will have an impact on achieving the work target of community midwives as described in PWS-KIA [5]. Excessive workload will cause tension, prone to making mistakes, irritability, reduce self-confidence and insomnia. A worker will be motivated to do work creatively, calmly and optimally if the work load given is optimal [6].

Timeliness in completing work is very important to support the principle of efficiency. Midwives must understand that time is a resource that must be used properly and practiced on the tasks given to them on time. The time a worker uses to complete his work can be classified into productive and non-productive time. Productive time is time that is actually used to complete work, while non-productive time is working time that is not used to complete work [2]. Quality refers to the quality that results from doing a job. The quality of midwifery services can be seen in the achievement of the midwifery service coverage target which is the main task of midwives as well as additional duties as an effort to reduce MMR [7].

In Indonesia, maternal mortality and neonatal mortality are still big challenges and need to pay attention to during the COVID-19 pandemic situation. Of the total patients infected with the COVID-19, 2.4\% were children aged $0-5$ and $1.3 \%$ died. For the group of pregnant women, there were $4.9 \%$ of pregnant women who tested positive for the COVID-19. This data shows that pregnant women, childbirth, infants and newborns are vulnerable targets of the COVID-19 infection and this condition is feared to increase morbidity and mortality of mothers and newborns. In the COVID-19 pandemic situation, there are many restrictions to almost all routine services including maternal and newborn health services. For example, pregnant women are reluctant to go to Puskesmas or other health service facilities because they are afraid of being infected. There are recommendations to postpone pregnancy examinations and classes for pregnant women, as well as unprepared services in terms of personnel and infrastructure including Personal Protective Equipment. This causes maternal and infant health services to have an impact both in terms of access and quality [8].

This study aims to analyze the work productivity of midwives in community midwifery services during the Covid-19 Pandemic in terms of work quantity, work quality and timeliness of completing work 


\section{Methodology}

This research applied an analytical survey research using cross sectional method. The population of this study were all midwives who worked as village midwives or midwives at Puskesmas. The research sample was 182 people, who met the inclusion criteria, namely currently working as a village midwife or Puskesmas, working as a midwife at that place for at least one year and willing to be a respondent.

The research instrument used was a closed questionnaire with a Likert scale consisting of 15 question items. It measured three productivity indicators, namely quantity of work, timeliness of completing work and quality of work, which each indicator consisted of 5 questions. The instrument has been tested for validity and reliability with a value of 0.83 . The research instrument was distributed using Google Form, on February 2 - March 2, 2021. The gathered data were reduced by the researcher according to the inclusion criteria. The appropriate data was processed and analyzed with the output in a reference distribution table or graph.

\section{Result and Discussion}

Based on the results of the research data reduction, there were 182 respondents who participated in this study and were selected by using the inclusion criteria. The description of respondents' characteristics based on age, education and length of work can be seen in the Table 1 bellow.

Table 1. Respondents' characteristics based on Age, Education, and Work experience

\begin{tabular}{|c|c|c|c|}
\hline \multirow[t]{2}{*}{ No } & \multirow{2}{*}{ Variable } & \multicolumn{2}{|c|}{ Frequency distribution } \\
\hline & & $\mathbf{N}$ & $\%$ \\
\hline \multirow[t]{4}{*}{1} & Age & & \\
\hline & $<25$ years & 28 & 15,4 \\
\hline & $25-35$ years & 143 & 78,6 \\
\hline & $>35$ years & 11 & 6,0 \\
\hline \multirow[t]{3}{*}{2} & Education & & \\
\hline & 3-year Diploma of Midwifery & 154 & 84,6 \\
\hline & 4-year Diploma of Midwifery & 28 & 15,4 \\
\hline \multirow[t]{6}{*}{3} & Work experience & & \\
\hline & $1-5$ years & 102 & 56,0 \\
\hline & $5-10$ years & 64 & 32,5 \\
\hline & $10-15$ years & 7 & 3,8 \\
\hline & $>15$ years & 9 & 4,9 \\
\hline & Total & 182 & 100 \\
\hline
\end{tabular}


Based on the table 1 above, it shows that the characteristics of respondents based on age are mostly aged $25-35$ years $(78.6 \%)$. Those who are still in the productive period usually have a higher level of productivity compared to older workers so that their physical abilities become weak and limited [9]. A person's work productivity will decrease as the age increases. Work productivity is related to speed, dexterity, strength, and coordination in completing work which decreases over time [10]. Therefore, midwives who work at productive age should have good work productivity. The productive age can be seen as the best career peak for a midwife. The reason is precisely because it relates to the speed and dexterity in providing community midwifery care and requires coordination with various parties in order to achieve health service efforts in the community.

Moreover, based on their education, most of the midwives graduated from a 3-year diploma of Midwifery (84.6\%). This shows that most midwives who provide community midwifery services are in accordance with the minimum educational qualifications of midwives as prescribed in Law Number 4 concerning Midwifery of 2019, article 43 paragraph 1 which states that midwives who have a 3-year diploma education can only carry out Midwifery Practices in health service facilities [11]. Education has an impact on the roles and responsibilities of midwives in providing midwifery care. A three-year diploma of education is a minimum standard for a midwife in performing midwifery services independently and collaboratively as well as in making referrals to health and community service facilities.

Based on their work experience as midwives, most of the midwives worked 1- 5 years $(56.0 \%)$. It can be inferred that mastery of work still needs to be improved. It is important because the mastery of work can facilitate a job and tasks to be carried out. If a job has been mastered, then the job will be easy and fast to complete [12]. Work productivity is related to mastery of work. Mastery of work in midwifery services is very important because it requires a midwife to master certain skills in providing midwifery care. In essence, midwifery practice is also an art in providing comprehensive midwifery services.

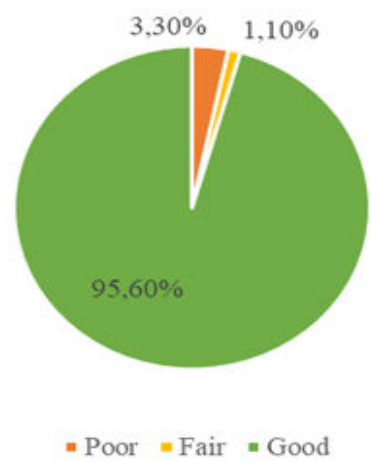

Fig 1. Midwives Productivity in Community Services during the COVID-19 Pandemic

The figure 1 above revealed that most of the midwives work productivity in community midwifery services during the COVID-19 pandemic was in the good category $(95.6 \%)$ but there were still midwives with fair $(1.1 \%)$ and poor $(3.3 \%)$. work productivity. In other words, the productivity of midwives needs to be carried out by increasing the aspects of knowledge and skills (technical skills). According to Alan Lawlor, productivity is a comparison between the output or result and the resources used in carrying out its activities (input) [13]. Productivity is basically a mental attitude that always has the view that the quality of life 
today must be better than yesterday, and today is done for the good of tomorrow. Work productivity is strongly influenced by several factors such as work motivation, work ethic, discipline, skills and education.

Moreover, it can also be influenced by factors of equipment, methods and work environment which greatly affect productivity. To get high productivity, these factors must be completely compatible with the abilities, capabilities and limitations of human workers [14]. Research conducted by Frimpong, et al in 2011 showed that there was an increase in the work productivity of midwives by $31 \%$ in providing care to patients. In other words, there was a 2fold increase in the productivity of midwives (Odds ratio=1.53-1.57) if the work is supervised by a supervisory team from the sub-district or district [15]. Work supervision can have a positive impact on the work productivity of midwives since they receive support from superiors or supervisors in providing midwifery services professionally. Thus, positive and supportive supervision has an impact on the output of the health care system, especially midwifery services.

In addition, research conducted by Sullivan, et al in 2011 revealed that work productivity could also be influenced by the pride of midwife profession, work motivation and job satisfaction. The highest percentage of being proud of their profession was $94 \%$ and work motivation was $94 \%$. therefore, they have a positive view about their profession. Job satisfaction (99\%) due to the presence of a midwife makes a difference for women [16]. Achieving good work productivity, midwives need to maintain good midwifery relationships with women and their families as well as relationships with co-workers. In other words, professional identity as midwives is truly essential in carrying out midwifery practices.

During the COVID-19 pandemic, the productivity of midwives in Indonesia was still in the good category. The midwives performed midwifery services in accordance with standard operating procedures (SOPs) and the roles and functions of midwives in the community. However, restrictions have been made on maternal and child health services. For example, counseling health services were carried out online, clients who wanted to get midwifery services were screened for risk factors of Covid-19 and clients must pay attention to health protocols. The clients must reduce the frequency of pregnancy visits, post-partum mother visits and newborns were carried out once with a midwife. The subsequent practices were carried out by the clients themselves by utilizing the Maternal and Child Health book or guidance on pregnancy exercises and postpartum exercises were carried out online.

Based on the results of the gathered data, it was discovered that generally midwives did not conduct classes for pregnant women and classes for mothers of toddlers. Consequently, pregnant exercise guidance activities and monitoring child growth and development were not carried out online. This was also due to the lack of creativity of midwives in utilizing appropriate technology that supports midwifery services. In fact, the majority of clients have supporting facilities such as android-based cellphones.

The COVID-19 pandemic requires midwives to develop technology-based models of Midwifery services such as the use of What's-up so that midwifery services that must be carried out online can still be carried out despite the COVID-19 pandemic. In addition, midwives can also take advantage of social media in providing midwifery services such as Facebook, Instagram or YouTube which can be accessed by clients in providing information on maternal and child health. 
Table 1. Work productivity based on indicators of work quantity, timeliness, and work quality

\begin{tabular}{|c|c|c|c|}
\hline \multirow[t]{2}{*}{ No } & \multirow[t]{2}{*}{ Variable } & \multicolumn{2}{|c|}{ Frequency distribution } \\
\hline & & $\mathbf{N}$ & $\%$ \\
\hline \multirow[t]{3}{*}{1} & Work quantity & & \\
\hline & Many & 164 & 90.1 \\
\hline & Little & 18 & 9.9 \\
\hline \multirow[t]{3}{*}{2} & Timeliness & & \\
\hline & On time & 147 & 80.8 \\
\hline & Not on time/late & 35 & 19.2 \\
\hline \multirow[t]{4}{*}{3} & Work quality & & \\
\hline & Good & 164 & 90.1 \\
\hline & Poor & 18 & 9.9 \\
\hline & Total & 182 & 100 \\
\hline
\end{tabular}

The results showed that in terms of work quantity most of the midwives carried out a large number of midwifery services $(90.1 \%)$, but there were a small number of midwives who carried out small amount of work $(9.9 \%)$. The work quantity of a midwife is related to the amount of work that must be completed in accordance with her responsibilities and authorities. The number of jobs of midwives who work at the Puskesmas will be different from the number of jobs of midwives who work as administrators at Polindes, Poskesdes or PKD. The basic reason of this difference is because midwives at the Puskesmas are not only responsible for maternal and child health services but also health services as a whole ranging from simple medication, surveillance of infectious diseases, to nutrition service, and other services.

Therefore, too much work will have an impact on achieving the work target of community midwives as described in PWS-KIA [5]. Good work productivity can be produced if all the duties and responsibilities of the midwife can be carried out. Therefore, midwives who provide community midwifery services need to make a priority scale of problems in their working areas so as to make it easier to discover the solutions to midwifery problems.

Most midwives are punctual in completing their work $(80.8 \%)$, but there are midwives who are not on time or late in completing their work (19.2\%). Punctuality in completing work is very important to support the principle of efficiency. Midwives must understand that time is a resource that must be used properly and practiced in order the tasks given to them get finished on time. The spending time that a worker uses to complete his work can be classified into productive and non-productive time. Productive time is time that is actually used to complete work, while non-productive time is working time that is not used to complete work [2].

Midwives must be able to use productive time well by not delaying the work that is supposed to be the responsibility of the midwife and start working in accordance with the applicable working time provisions. By applying the efficiency principle, the productivity of midwives can be achieved well. 
Based on the work quality, most of the midwives have good work quality $(90.1 \%)$, while others have poor work quality $(9.9 \%)$. Quality refers to the quality that results from doing a job. The quality of midwifery services can be seen in the achievement of the midwifery service coverage target. It is the main task of midwives aside from the additional tasks such as an effort to reduce the Maternal Mortality Rate, Infant Mortality Rate and the Under-Five Mortality Rate [7]. The work quality can be achieved depending on the amount of work completed with the timeliness of completing the work. Midwives have their own duties and responsibilities as a community midwife. The number of jobs will be different from that of a midwife who does not work in the community. In completing their duties, the midwife must achieve the agreed midwifery service coverage target for a work area.

\section{Conclusion}

The work productivity of midwives in community midwifery services during the Covid19 pandemic is in the good category. So, it can be concluded that the work productivity of midwives is determined through some indicators on their work quantity and most of them complete their work according to the specified time so that the quality of their work is good. Good work productivity is highly dependent on the quantity of work, efficiency of working time and quality of work. The more work completed using the best possible time, the better the quality of the work.

In order to increase the work productivity of midwives, it is necessary to carry out supportive supervision by sub-district or district supervisors. The presence of supervisors not only supervises midwifery practice in the community but rather examines important information related to needs, barriers and potentials that can be used for the achievement of quality midwifery services. Further researchers need to conduct a research related to the work productivity of midwives with the achievement of targets for maternal and child health indicators in community midwifery services.

\section{References}

[1] Kementrian Kesehatan Republik Indonesia, "Profil Kesehatan Indonesia 2019." Kementerian Kesehatan Indonesia, Jakarta, 2020.

[2] A. Kurniati and F. Effendi, Kajian SDM Kesehatan di Indonesia. Jakarta: Salemba Medika, 2012.

[3] K. Kesehatan, Pedoman Pelayanan Atenatal Tertapadu. Jakarta: Kementerian Kesehatan RI, 2010.

[4] A. P. Mangkunegara, Manajemen sumber daya manusia perusahaan, 4th ed. Bandung: PT RemajaRosdakarya Offset, 2013.

[5] K. Y. A. Melati, P. A. Wigati, and S. P. Arso, "Analisis beban kerja bidan desa di puskesmas duren kabupaten semarang,” J. Kesehat. Masy., vol. 3, no. April, pp. 30-40, 2015.

[6] A. S. Munandar, Psikologi Industri dan Organisasi. Jakarta: UI Pres, 2001.

[7] Kemenkes RI, "Pedoman Pemantauan Wilayah Setempat Kesehatan Ibu dan Anak (PWS-," Kementrian Kesehat. RI, Direktorat Jendral Bina Kesehat. Masyarakat, Direktorat Bina Kesehat. Ibu, p. 1 of 76, 2010.

[8] C. Muliati, Erna dr. M.Sc, Pedoman Pelayanan Bagi Ibu Hamil, Bersalin, Nifas, Dan Bayi Baru Lahir di Era Pandemi COVID-19. 2020.

[9] A. Selvia, "Pengaruh Usia dan Masa Kerja Terhadap Produktivitas Kerja (Studi Kasus: PT. OASIS Water International Cabang Palembang),” J. Sist. dan Manaj. Ind., vol. 2, no. 1, 2017.

[10] W. Bangun, Manajemen sumber daya manusia, 1st ed. Jakarta: Erlangga, 2012. 
[11] "UNDANG-UNDANG REPUBLIK INDONESIA NOMOR 4 TAHUN 2019 TENTANG KEBIDANAN.” 2019.

[12] P. . Senudin, E. . Padeng, E. . Masri, and Y. Suryati, "The Utilization Of Counseling Flipchart At Integrated Health Post,” J. Kesehat. Prima, vol. 14, no. August, pp. 93-96, 2020.

[13] A. Lawlor, Manual Perbaikan Produktivitas, 1st ed. Jakarta: Lembaga Sarana Informasi Usaha dan Produktivitas.

[14] Tarwaka, H. S. Bakri, and L. Sudiajeng, Ergonomi untuk Keselamatan, Kesehatan Kerja dan Produktivitas, 1st ed. Surakarta: UNIBA PRESS, 2004.

[15] J. A. Frimpong, S. Helleringer, A. J. K. Williams, F. Yeji, and J. F. Phillips, "Does supervision improve health worker productivity? Evidence from the Upper East Region of Ghana," Trop. Med. Int. Heal., vol. 16, no. 10, pp. 1225-1233, 2011, doi: 10.1111/j.1365-3156.2011.02824.x.

[16] K. Sullivan, L. Lock, and C. S. E. Homer, "Factors that contribute to midwives staying in midwifery: A study in one area health service in New South Wales, Australia," Midwifery, vol. 27, no. 3, pp. 331-335, 2011, doi: 10.1016/j.midw.2011.01.007. 